\title{
BIOCHEMICAL OBSERVATIONS ON THE CORPORA LUTEA OF THE AFRICAN ELEPHANT, LOXODONTA AFRICANA
}

\author{
JANET G. SMITH, ${ }^{*}$ J. HANKS $\uparrow$ AND R. V. SHORT* \\ * Department of Veterinary Clinical Studies, Madingley Road, Cambridge, \\ and †A.R.C. of Zambia, Mount Makulu, P.O. Box 49, Chilanga, Zambia
}

(Received 11th March 1969)

Summary. Luteal tissue slices from an African elephant in early pregnancy have been shown to synthesize progesterone from added pregnenolone. The percentage conversion $(2.4 \% / 100 \mathrm{mg}$ luteal tissue $/ \mathrm{hr})$ is very much lower than that found for human, bovine and porcine corpora lutea. It was possible to isolate a small amount of progesterone $(0.18 \mu \mathrm{g} / \mathrm{g})$ from a large quantity of luteal tissue taken from another pregnant elephant; this is far below the values found in the active corpora lutea of all other mammals.

The reasons for the relative inability of elephant corpora lutea to synthesize progesterone are not known. The elephant may be extremely sensitive to the action of progesterone, or the hormone may not be necessary for normal reproduction in this species.

\section{INTRODUCTION}

Previous studies on the corpora lutea of the African elephant, Loxodonta africana, failed to demonstrate the presence of any progesterone in this tissue. Corpora lutea from five animals in early, mid and late pregnancy and from three non-pregnant animals at various stages of the oestrous cycle contained less than $0 \cdot 1$ to $0 \cdot 2 \mu \mathrm{g}$ progesterone/g luteal tissue (Short \& Buss, 1965; Short, 1966), whereas the concentrations in the functional corpora lutea of other mammals range from about 10 to $100 \mu \mathrm{g} / \mathrm{g}$ tissue.

The purpose of the present investigation was two-fold; firstly to see whether fresh elephant luteal tissue contained the enzyme systems necessary for the conversion of pregnenolone ( $3 \beta$-hydroxypregn-5-en-20-one) to progesterone, and secondly to see whether progesterone could be isolated from a large pool of elephant corpora lutea.

\section{MATERIALS AND METHODS}

Incubation studies

A 43-year-old female elephant, whose age was estimated from the degree of molar tooth wear (Laws, 1966), was shot in the Luangwa Valley, Zambia. The animal was lactating with a calf estimated to be about 2 years old at foot, 
and was pregnant with a $1590-\mathrm{g}\left(3 \frac{1}{2}-1 \mathrm{~b}\right)$ male foetus in the left uterine horn. The estimated gestation age calculated from the data of Perry (1953) was about 7 months, the total length of gestation being about 22 months. The left ovary contained one $30-\mathrm{mm}$ diameter corpus luteum and fifteen brown, regressed corpora lutea. The right ovary contained one $35-\mathrm{mm}$ diameter corpus luteum which was used for the incubation study, three other corpora lutea of 23-, 17 and 16-mm diameter, and eight brown, regressed corpora lutea.

The ovaries were removed within 13 min of death, placed on ice in a thermos flask, and flown immediately to Chilanga. On arrival in the laboratory, the largest corpus luteum was dissected out of the right ovary and cut into thin slices. Incubation flasks were then set up as shown in Table 1.

The $\left[7 \alpha^{-3} \mathrm{H}\right]$ pregnenolone added to flasks 1 and 3 had a specific activity of $500 \mathrm{mCi} / \mathrm{m}$-mole ( $1.58 \mathrm{mCi} / \mathrm{mg}$; The Radiochemical Gentre, Amersham, Bucks.) and was used without any pre-purification. The elephant serum was obtained by collecting freshly flowing jugular vein blood from the same elephant. The blood was allowed to stand until a clot had formed, the serum that was removed from it being decanted into a sterile bottle.

TABLE 1

IN VITRO INGUBATION OF $\left[7 \alpha-{ }^{3} \mathrm{H}\right]$ PREGNENOLONE WITH ELEPHANT LUTEAL TISSUE IN 10 ML SERUM FOR 1 HR AT $37^{\circ} \mathrm{C}$

\begin{tabular}{|c|c|c|c|c|c|c|}
\hline Flask no. & Description & $\begin{array}{l}\text { Luteal tissue } \\
\quad(m g)\end{array}$ & \multicolumn{2}{|c|}{$\begin{array}{l}\text { Pregnenolone added } \\
\mu \mathrm{Ci} \quad \mu \mathrm{g}\end{array}$} & \multicolumn{2}{|c|}{$\begin{array}{l}\text { Progesterone formed } \\
\mu \mathrm{Ci} \% \text { conversion }\end{array}$} \\
\hline $\begin{array}{l}1 \\
2 \\
3\end{array}$ & $\begin{array}{l}\text { Medium control } \\
\text { Tissue control } \\
\text { Experimental }\end{array}$ & $\begin{array}{c}0 \\
111 \cdot 1 \\
99 \cdot 7\end{array}$ & $\begin{array}{r}10 \\
0 \\
10\end{array}$ & $\begin{array}{l}6 \cdot 3 \\
0 \\
6 \cdot 3\end{array}$ & $\begin{array}{l}0 \cdot 018 \\
0 \\
0 \cdot 24\end{array}$ & $\begin{array}{l}0 \cdot 18 \\
0 \\
2 \cdot 4\end{array}$ \\
\hline
\end{tabular}

Incubations were carried out for $1 \mathrm{hr}$ at $37^{\circ} \mathrm{C}$ in air and were started $4 \mathrm{hr}$ $10 \mathrm{~min}$ after the death of the elephant. At the end of the incubation, $50 \mathrm{ml}$ absolute ethanol were added to each flask and the samples were then flown to Cambridge and subsequently stored at $-20^{\circ} \mathrm{C}$ until they could be extracted. Immediately before extraction, $0.01 \mu \mathrm{Gi}, 0.072 \mu \mathrm{g}\left[4-{ }^{14} \mathrm{C}\right]$ progesterone was added to each flask, followed by $50 \mathrm{ml}$ absolute methanol. Following homogenization in methanol, the pooled methanolic extracts were evaporated to about $10 \mathrm{ml}$, diluted with distilled water, and extracted with ethyl acetate; the extract was then evaporated to dryness. After partitioning between petroleum ether and $70 \%$ aqueous methanol, the methanolic extracts were evaporated to dryness and chromatographed on paper in a ligroin $/ 80 \%$ methanol system, together with a standard of authentic progesterone.

The paper chromatograms were run through a windowless gas-flow strip scanner (Frieseke \& Hoepfner), and the zone corresponding to progesterone was eluted. Thirty $\mathrm{mg}$ of authentic progesterone were added to the eluate as carrier and the progesterone was recrystallized from various solvents. After the third re-crystallization, the crystals from the experimental flask were dissolved in absolute methanol and reduced with sodium borohydride. Chromatography of the reaction product showed that the major compound had the 
$R_{F}$ value of $20 \beta$-hydroxypregn-4-en-3-one. The reaction product was then recrystallized a further three times from various solvents. Aliquots of all crystals and mother liquors were taken for counting, and the ${ }^{14} \mathrm{C}:{ }^{3} \mathrm{H}$ ratios determined.

A similar procedure was carried out with the medium control, except that the progesterone was recrystallized to constant ${ }^{14} \mathrm{C}:{ }^{3} \mathrm{H}$ ratios without derivative formation.

\section{Isolation studies}

A female elephant, aged $14 \frac{1}{2}$ years as judged by the criteria of Laws (1966), was shot in the Mkomasi cropping scheme in Northern Tanzania. The animal was not lactating, but was pregnant, probably for the first time, and contained a 105-g female foetus with an estimated gestation age of less than 4 months (Perry, 1953). The ovaries were removed within $\frac{1}{2} \mathrm{hr}$ of death and frozen until they could be dissected. Numerous corpora lutea were present, and they were dissected out and placed in a large volume of ethanol. On arrival in Cambridge, the sample was stored at $+5^{\circ} \mathrm{C}$ until extraction.

The luteal tissue was first weighed $(36.6 \mathrm{~g})$ and after the addition of $0.5 \mu \mathrm{Ci}$, $0.0135 \mu \mathrm{g}\left[7 \alpha-{ }^{3} \mathrm{H}\right]$ progesterone, it was thoroughly homogenized first in the ethanol in which it had been stored and then in methanol. The pooled alcoholic extracts were evaporated to a small volume, and cooled to $-20^{\circ} \mathrm{C}$ overnight. After filtration, the precipitate was removed, and the filtrate was diluted with distilled water and then extracted with ethyl acetate.

The dried ethyl acetate extracts were treated with Girard's reagent $\mathrm{T}$ and separated into ketonic and non-ketonic fractions (Pincus \& Pearlman, 1941); the non-ketonic fraction was discarded. The ketonic fraction was partitioned between petroleum ether and $70 \%$ methanol and the methanolic fraction was chromatographed on paper. The progesterone zone was eluted, treated with a few drops of acetic anhydride and pyridine (1:1) overnight, and re-chromatographed on paper. After eluting the progesterone area, 1/10-aliquots were removed for liquid scintillation counting and for gas chromatography. The remaining four-fifths were treated with $20 \beta$-hydroxysteroid dehydrogenase (Henning \& Zander, 1962), and the reaction product re-chromatographed on paper with a standard of $20 \beta$-hydroxypregn-4-en-3-one. After elution, half the eluate was used for counting and gas chromatography, whilst the remainder was acetylated overnight with acetic anhydride and pyridine, re-chromatographed on paper, and the $20 \beta$-acetoxypregn-4-en-3-one zone finally eluted, counted and quantitated by gas chromatography. All the results were corrected for extraction losses.

\section{Radio-active counting procedures}

Samples were counted in a Packard Tricarb Model 3003 Liquid Scintillation Gounter. The counting efficiencies in the two channels used were: Ghannel 1, ${ }^{3} \mathrm{H}, 30 \cdot 3 \%,{ }^{14} \mathrm{C}, 15 \cdot 0 \%$; Channel $2,{ }^{3} \mathrm{H}, 0 \%,{ }^{14} \mathrm{C}, 52 \cdot 4 \%$. The scintillator used throughout was prepared by dissolving $5 \mathrm{~g}$ PPO and $0.3 \mathrm{~g}$ dimethyl POPOP in 1 litre redistilled A.R. toluene. 
Gas chromatography

This was carried out in an F \& M model 400 instrument with a $4 \mathrm{ft}$ column of $3.8 \%$ S.E. 30 on Diatoport S 80 to 100 mesh, at a temperature of $225^{\circ}$ C. Quantitation was achieved by using an internal standard of $20 \beta$-acetoxypregn4-en-3-one or progesterone as appropriate. Peak areas were recorded by cutting out and weighing the tracings produced by the chart recorder.

\section{RESULTS}

Incubation studies

Table 1 shows that only a small proportion of the added pregnenolone was converted to progesterone by luteal tissue in the l-hr incubation period. A trace of progesterone was also detected in the medium control, to which no tissue had been added. This could have been due to contamination of the original sample of $\left[7 \alpha-{ }^{3} \mathrm{H}\right]$ pregnenolone with progesterone.

Most of the remaining radio-activity in the experimental flask appeared to be unchanged pregnenolone, as judged by its $R_{F}$ value on the paper chromatogram before and after acetylation.

TABLE 2

RE-GRYSTALLIZATION DATA

\begin{tabular}{|c|c|c|c|}
\hline \multirow{2}{*}{ Steroid } & \multirow{2}{*}{ Solvent } & \multicolumn{2}{|c|}{${ }^{14} \mathrm{C}:{ }^{3} \mathrm{H}$ ratio } \\
\hline & & Crystals & Mother liquor \\
\hline $\begin{array}{l}\text { Experimental flask } \\
\text { Progesterone } \\
\text { Progesterone } \\
\text { Progesterone } \\
\text { 20 } \beta \text {-Hydroxy-pregn-4-en-3-one } \\
\text { 20 } \beta \text {-Hydroxy-pregn-4-en-3-one } \\
\text { 20 } \beta \text {-Hydroxy-pregn-4-en-3-one }\end{array}$ & $\begin{array}{l}\text { Acetone: Ligroin } \\
\text { Methanol: Ligroin } \\
40 \text { to } 60^{\circ} \text { Pet. ether } \\
60 \text { to } 80^{\circ} \text { Pet. ether: Methanol } \\
60 \text { to } 80^{\circ} \text { Pet. ether } \\
60 \text { to } 80^{\circ} \text { Pet. ether }\end{array}$ & $\begin{array}{l}0.076 \\
0.078 \\
0.076 \\
0.070 \\
0.066 \\
0.070\end{array}$ & $\begin{array}{l}0 \cdot 046 \\
0 \cdot 069 \\
0 \cdot 074 \\
0 \cdot 072 \\
0 \cdot 071 \\
0 \cdot 066\end{array}$ \\
\hline $\begin{array}{l}\text { Medium control flask } \\
\text { Progesterone } \\
\text { Progesterone } \\
\text { Progesterone } \\
\text { Progesterone }\end{array}$ & $\begin{array}{l}\text { Methanol: Water } \\
60 \text { to } 80^{\circ} \text { Pet. ether } \\
\text { Methanol: Water } \\
60 \text { to } 80^{\circ} \text { Pet. ether }\end{array}$ & $\begin{array}{l}1 \cdot 20 \\
1 \cdot 17 \\
0 \cdot 80 \\
0 \cdot 84\end{array}$ & $\begin{array}{l}0 \cdot 11 \\
0 \cdot 30 \\
0 \cdot 78 \\
0 \cdot 71\end{array}$ \\
\hline
\end{tabular}

Table 2 shows that the progesterone formed by the luteal tissue was recrystallized to a constant ${ }^{14} \mathrm{C}:{ }^{3} \mathrm{H}$ ratio, which remained virtually the same after derivative formation. There can be no doubt, therefore, that elephant luteal tissue does possess the enzyme systems necessary to convert pregnenolone to progesterone.

\section{Isolation studies}

Progesterone appeared to be present in the large pool of luteal tissue $(36.6 \mathrm{~g})$ at a concentration of $0 \cdot 18 \mu \mathrm{g} / \mathrm{g}$. Since there was too little steroid available for further characterization by procedures such as infra-red or nuclear magnetic resonance spectroscopy, the specific activity of various derivatives was measured. Since the specific activity of the radio-active $\left[7 \alpha^{3} \mathrm{H}\right]$ progesterone added at the beginning of the extraction was $2 \times 10^{6}$ counts $/ \mathrm{min} / \mu \mathrm{g}$, the lower 
specific activities shown in Table 3 suggest that progesterone was definitely present in the extract. The fact that the specific activity remained relatively constant after the formation of two derivatives could be taken as reasonable evidence for the isolation of progesterone from elephant corpora lutea. However, the concentration found even at this very early stage of pregnancy was exceedingly low.

TABLE 3

SPECIFIC ACTIVITIES OF PROGESTERONE ISOLATED FROM ELEPHANT LUTEAL TISSUE

\begin{tabular}{c|c}
\hline Sample & $\begin{array}{c}\text { Specific counts/min/ } \\
\mu g \text { activity }\end{array}$ \\
\hline $\begin{array}{l}\text { (1) Progesterone eluted from second chromatogram after treatment with acetic } \\
\text { anhydride and pyridine }\end{array}$ & 3679 \\
(2) $20 \beta$-Hydroxypregn-4-en-3-one, produced by treating (1) with 20 $\beta$-hydroxy- \\
steroid dehydrogenase and re-chromatographing reaction product on paper \\
(3) $20 \beta$-Acetoxypregn-4-en-3-one, produced by treating (2) with acetic \\
anhydride and pyridine and re-chromatographing reaction product on \\
paper. Two aliquots
\end{tabular}

An internal isotope standard of $\left[7 \alpha^{3} \mathrm{H}\right]$ progesterone $(0.5 \mu \mathrm{Ci}, 0.0135 \mu \mathrm{g})$ was added at the beginning of the extraction procedure.

\section{DISCUSSION}

Pregnenolone is normally converted to progesterone in very high yield by luteal tissue in a variety of different mammals. Duncan, Bowerman, Hearn \& Melampy (1960) found that pig luteal slices incubated in a Krebs Ringer bicarbonate buffer with glucose converted up to $74 \%$ of pregnenolone to progesterone in $2 \mathrm{hr}$, even when the amount of pregnenolone added was as great as $794 \mu \mathrm{g} / \mathrm{g}$ luteal tissue. Ryan \& Smith (1965), using slices of human corpus luteum, found an almost complete conversion of pregnenolone to progesterone and other steroids in $4 \mathrm{hr}$. Armstrong \& Black (1966) found that even regressing bovine corpora lutea, collected on Days 19 to 21 of the oestrous cycle, retained the ability to synthesize large amounts of progesterone from added pregnenolone. The granulosa cells of the mare can even convert pregnenolone to progesterone in high yield before they have begun to luteinize (Short, 1964).

The incubation study described here has demonstrated that although elephant luteal tissue does contain the enzyme systems necessary for converting pregnenolone to progesterone, the percentage conversion after a l-hr incubation was only $2.4 \%$. Most of the radio-activity could be accounted for as unchanged pregnenolone. This finding is in keeping with the very small amount of progesterone detected in elephant luteal tissue, $0.18 \mu \mathrm{g} / \mathrm{g}$. This amount would have been at the limit of sensitivity of the assay procedure in our previous studies, when we failed to detect progesterone in elephant corpora lutea collected from animals at various stages of the oestrous cycle and pregnancy (Short \& Buss, 1965; Short, 1966).

Table 4 lists the maximum concentrations of progesterone found in the corpora lutea of a wide variety of mammals, including the Hyrax, which is 
TABLE 4

MAXIMUM GONCENTRATIONS OF PROGESTERONE IN LUTEAL TISSUE OF VARIOUS SPECIES

\begin{tabular}{|c|c|c|}
\hline Species & Reference & $\begin{array}{l}\text { Progesterone } \\
\text { ( } \mu \text { g/g tissue) }\end{array}$ \\
\hline $\begin{array}{l}\text { Grant's zebra (Equus burchelli böhmi) } \\
\text { Grevy's zebra (Equus grevyi) } \\
\text { Badger (Meles meles) } \\
\text { Pig (Sus scrofa) } \\
\text { Dog (Canis familiaris) } \\
\text { Cow (Bos taurus) } \\
\text { Sheep (Ovis aries) } \\
\text { Human (Homo sapiens) } \\
\text { Horse (Equus caballus) } \\
\text { Coypu (Myocastor coypus) } \\
\text { Guinea-pig (Cavia porcellus) } \\
\text { Whale (various species) } \\
\text { Roe deer (Capreolus capreolus) } \\
\text { Armadillo (Dasypus novemcinctus) } \\
\text { Hippopotamus (Hippopotamus amphibius) } \\
\text { Wallaroo (Macropus robustus) } \\
\text { Hyrax (Proxavia sp.) } \\
\text { Red kangaroo (Megaleia rufa) } \\
\text { Seal (Phoca vitulina) } \\
\text { African elephant (Loxodonta africana) }\end{array}$ & $\begin{array}{l}\text { King (1965) } \\
\text { King (1965) } \\
\text { Canivenc et al. (1966) } \\
\text { Masuda et al. (1967) } \\
\text { Telegdy \& Endröczi (1961) } \\
\text { Gomes \& Erb (1965) } \\
\text { Deane et al. (1966) } \\
\text { Zander et al. (1958) } \\
\text { Short (1958) } \\
\text { Rowlands \& Heap (1966) } \\
\text { Rowlands \& Short (1959) } \\
\text { Prelog \& Meister (1949) } \\
\text { Short \& Hay (1966) } \\
\text { Labhsetwar \& Enders (1968) } \\
\text { Laws \& Clough (1966) } \\
\text { Short \& Sharman (unpublished) } \\
\text { Short (unpublished) } \\
\text { Short \& Sharman (unpublished) } \\
\text { Short (1958) } \\
\text { Present study }\end{array}$ & $\begin{array}{r}233 \cdot 9 \\
203 \cdot 0 \\
89 \cdot 2 \\
87 \cdot 0 \\
83 \cdot 0 \\
73 \cdot 2 \\
50 \cdot 0 \\
49 \cdot 8 \\
46 \cdot 0 \\
39 \cdot 0 \\
37 \cdot 6 \\
33 \cdot 0 \\
30 \cdot 0 \\
26 \cdot 0 \\
19 \cdot 0 \\
15 \cdot 2 \\
9 \cdot 9 \\
9 \cdot 2 \\
7 \cdot 1 \\
0 \cdot 18\end{array}$ \\
\hline
\end{tabular}

often regarded as the closest living relative of the elephant. The concentrations in all these species are at least 40 times higher than the concentrations in elephant corpora lutea. One explanation may be that the elephant is extremely sensitive to the action of steroid hormones; however, in male elephants the concentration of testosterone in testicular tissue is similar to that of other mammals (Short, Mann \& Hay, 1967). A more exciting possibility is that progesterone is not an essential hormone of reproduction in the elephant.

\section{ACKNOWLEDGMENTS}

We would like to thank $\mathrm{R}$. Langerveld for shooting the elephant in the Luangwa Valley, and the Director of the Department of Game and Fisheries in Zambia for providing the aircraft to fly the fresh material to Chilanga. W. R. Carr of the A.R.C. of Zambia assisted with the incubation experiment. Dr R. M. Laws kindly provided the corpora lutea from the elephant shot in the Mkomasi cropping scheme in Tanzania, and we are most grateful to the Wellcome Trust for financial support.

\section{REFERENCES}

ARmstrong, D. T. \& BlaCK, D. L. (1966) Influence of luteinizing hormone on corpus luteum metabolism and progesterone biosynthesis throughout the bovine estrous cycle. Endocrinology, 78, 937.

Canivenc, R., Short, R. V. \& Bonnin-Laffargue, M. (1966) Etude histologique et biochimique du corps jaune du blaircau européen (Meles meles L). Annls Endocr. 27, 401 .

Deane, H. W., Hay, M. F., Moor, R. M., Rowson, L. E. A. \& Short, R. V. (1966) The corpus luteum of the sheep: relationship between morphology and function during the oestrous cycle. Acta endocr., Copenh. 51, 245.

Duncan, G. W., Bowerman, A. M., Hearn, W. R. \& Melampy, R. M. (1960) In vitro synthesis of progesterone by swine corpora lutea. Proc. Soc. exp. Biol. Med. 104, 17.

Gomes, W. R. \& ERB, R. E. (1965) Progesterone in bovine reproduction-a review. 7. Dairy Sci. 48, 314. 
Henning, H. D. \& Zander, J. (1962) Verwendung von Hübeners 20 $\beta$-Hydroxysteroid-Dehydrogenase bei mikrochemischer Identifizierung und Trennung von Steroiden. Hoppe-Seyler's Z. physiol. Chem. 330, 31.

KING, J. M. (1965) Comparative aspects of reproduction in Equidae. Ph.D. dissertation, University of Cámbridge.

Labhsetwar, A. P. \& Enders, A. C. (1968) Progesterone in the corpus luteum and placenta of the armadillo, Dasypus novemcinctus. 7. Reprod. Fert. 16, 381.

LAws, R. M. (1966) Age criteria for the African elephant, Loxodonta a. africana. E. Afr. Wildl. Jnl, 4, 1.

Laws, R. M. \& Clough, G. (1966) Observations on reproduction in the hippopotamus, Hippopotamus amphibius Lin. Symp. zool. Soc. Lond. 15, 117.

Masuda, H., Anderson, L. L., Hendricks, D. M. \& Melampy, R. M. (1967) Progesterone in ovarian venous plasma and corpora lutea of the pig. Endocrinology, 80, 240.

Perry, J. S. (1953) The reproduction of the African elephant, Loxodonta africana. Phil. Trans. R. Soc. B, 237, 93.

Pincus, G. \& Pearlman, W. H. (1941) Fractionation of neutral urinary steroids. Endocrinology, $29,413$.

Prelog, V. \& Meister, P. (1949) Untersuchungen über Organextrakte und Harn. Úber die Isolierung von Progesteron aus dem Corpus Luteum des Wales. Helv. chim. Acta, 32, 2435.

Rowlands, I. W. \& Heap, R. B. (1966) Histological observations on the ovary and progesterone levels in the coypu, Myocastor coypus: Symp. zool. Soc. Lond. 15, 335.

Rowland, I. W. \& ShoRT, R. V. (1959) The progesterone content of the guinea-pig corpus luteum during the reproductive cycle and after hysterectomy. F. Endocr. 19, 81.

Ryan, K. J. \& Smrth, O. W. (1965) Biogenesis of steroid hormones in the human ovary. Recent Prog. Horm. Res. 21, 367.

Short, R. V. (1958) Progesterone in tissues and body fluids. Ph.D. dissertation, University of Cambridge.

Short, R. V. (1964) Ovarian steroid synthesis and secretion in vivo. Rec. Prog. Horm. Res. $20,303$.

Short, R. V. (1966) Oestrous behaviour, ovulation and the formation of the corpus luteum in the African elephant, Loxodonta africana. E. Afr. Wildl. $\mathbf{7 n l , 4 , 5 6 .}$

Short, R. V. \& Buss, I. O. (1965) Biochemical and histological observations on the corpora lutea of the African elephant, Loxodonta africana. 7. Reprod. Fert. 9, 61.

Shor', R. V. \& Hay, M. F. (1966) Delayed implantation in the roe deer, Capreolus capreolus. Symp. zool. Soc. Lond. 15, 173.

Short, R. V., MANN, T. \& HAy, M. F. (1967) Male reproductive organs of the African elephant, Loxodonta africana. 7. Reprod. Fert. 13, 517.

Telegdy, G. \& Endröczi, E. (1961) Progesterone content of the dog's ovarian venous blood and ovarian tissue. Acta physiol. hung. 20, 277.

Zander, J., Forbes, T. R., von Munstermann, A. M. \& Neher, R. (1958) $\Delta^{4}$-3-Ketopregnene-20 $\alpha-$ ol and $\Delta^{4}$-3-ketopregnene-20 $\beta$-ol, two naturally occurring metabolites of progesterone. Isolation, identification, biologic activity and concentration in human tissues. 7 . clin. Endocr. Metab. 18, 337 . 